\title{
European cooperation in gastroenterology
}

\section{First beginnings}

The necessity for European cooperation in gastroenterology is an old idea, which was first promulgated by the Belgian surgeon and radiologist Georges Brohee (1887-1957). This visionary man was the prime mover in organising the First International Congress of Gastroenterology in Brussels, 60 years ago, in 1935. This congress was a seminal event and marked the birth of European and, indeed, global cooperation in gastroenterology. ${ }^{1}$ On the last day of the congress, 10 August 1935, the Societe International de Gastroenterologie (SIGE) was founded. There were 12 founding member societies, nine from Europe (Belgium, France, Germany, Great Britain, Italy, Netherlands, Poland, Spain, and Switzerland) and three from the Americas (Argentina, Canada, and United States).

The Organization Mondial de Gastroenterologie (OMGE), developed historically from SIGE, it was founded in Paris in 1954 and constituted in Washington DC in 1958. In recognition of Brohee's contribution to global cooperation in gastroenterology, OMGE honours his memory with a medal and a lecture delivered at the quadrennial World Congress of Gastroenterology. After the Second World War, Brohee was again instrumental in organising an assembly of delegates of national societies of gastroenterology to deliberate and decide on the future of SIGE. A consensus at a global scale could not be reached, but it was decided to move towards the formation of a European forum. This idea bore fruit and on 11 October 1947, the Association des Societes Nationales Europeennes et Mediterraneennes de Gastroenterology (ASNEMGE) was founded.

\section{ASNEMGE and the dawn of European cooperation in gastroenterology}

ASNEMGE as a federation of national European and Mediterranean Societies of Gastroenterology and not individual members, encompasses a wide constituency and by virtue of its structure and function constitutes the titular organisation of gastroenterology in Europe and the Mediterranean. The International Congress of Gastroenterology organised by the ASNEMGE, initially biennially and later quadrennially, was the meeting point of European gastroenterology and allied disciplines from 1948 when the first congress took place in Lausanne and thereafter. The International Congress with the input and joint organisation with the European Society of Gastrointestinal Endoscopy (ESGE) contributed significantly to establish a forum of European exchange and scientific cooperation in gastroenterology.

The International Congresses were a venue for presentation of original research (generated primary in Europe) as well as education for the practising physician and gastroenterologist.

With the increasing trend, however, towards specialisation in research and the development of discipline oriented societies, the need for a concerted action in bringing together European gastroenterology and allied fields became a focus of concern among the leaders of these organisations. This eventually resulted in the formation of the United European Gastroenterology Federation (UEGF) and the United European Gastroenterology Week (UEGW).

\section{The new era: UEGF and UEGW}

After a period of arduous but, ultimately, rewarding planning, seven major European societies of gastroenterology formed the United European Gastroenterology Federation (Table). On a historical note it was fitting that the official foundation of UEGF took place on the Pnyx Hill, the site of the assembly of the ancient city of Athens, during the First United European Gastroenterology Week on 25 September $1992 .{ }^{2}$ It was, indeed, a major accomplishment in moving towards a closer cooperation in European gastroenterology and I am hopeful that history will judge us well on this account.

The UEGF council, which consists of two representatives from each society is a coordinating body whose aims are (a) to foster European cooperation in gastroenterology, (b) to conduct the affairs of the Federation and promote its interest, (c) to authorise the organisation of the UEGW by national societies and provide guidance through its scientific committee. The organisation of the annual UEGW in cooperation with the national organising society is at present the main focus of UEGF activity. Successful

\section{United European Gastroenterology Federation}

\footnotetext{
- Association des Societes Nationales Europeennes et Mediterraneennes de Gastroenterologie (ASNEMGE) - Association of National European and Mediterranean Societies of Gastroenterology Collegium Internationale Chirurgiae Digestivae (CICD-Europen Section)

European Assciation for Gastroenterology and Endoscopy (EAGE)

European Association for Study of the Liver (EASL) European Association for Study of
European Pancreatic Club (EPC)

European Pancreatic Club European Society for Pediatric Gastroenterology and
Nutrition (ESPGAN)
} 
congresses have so far taken place in Athens (1992), Barcelona (1993), Oslo (1994), and future congresses are planned in Berlin (1995), Paris (1996), Birmingham (1997), and Rome (1998).

The ultimate aim of the UEGW is to attract European researchers to present the best original work in Europe and not across the Atlantic. With this in mind, it should be noted that $40 \%$ of papers presented at the Digestive Disease Week in the United States originate from Europe. ${ }^{3}$

The growing need for a European forum, accommodating not only gastroenterology, but also special discipline oriented groups, to present original work in the same congress, was a significant factor in the formation of the UEGF. Understandably, any novel concept and formulation of ideas requires time and consistent effort to develop into a strong and respected institution. The UEGF and its week has made a good start, gained momentum, and moves toward a bright future.

\section{Future avenues of European cooperation in gastroenterology}

The lack of a strong tradition in scientific cooperation in Europe is offset by the existence of umbrella organisations, which should take a leading role in their respective field and expertise to foster collaborative activities at a multinational level.

These activities can be grouped together in five areas: research, education, training, audit, and ethics.

Research - we know very little about the epidemiology of gastrointestinal disease in Europe. There is a need for epidemiological data on incidence, aetiological factors, behaviour of disease, and response to treatment, in different countries and regions of Europe. Only well planned collaborative research can provide information on these aspects. The OMGE Research Committee has set up projects on acute abdominal pain and inflammatory bowel disease and valuable data have been collected.

Education - continuing medical education is becoming a necessity. It will not be long in Europe before licence renewal will be based on satisfying continuing medical education criteria, a requirement introduced in the United States long ago. Initiatives have been undertaken by several national societies, institutions, and the OMGE with regard to organising postgraduate courses in eastern European countries. To attract active participation it is preferable to organise seminars and post- graduate courses on site, with local organisation from national societies.

Training - in many European countries training programmes in gastroenterology are undergoing re-evaluation. Criteria for certification of training based on quality have been drawn up by the gastroenterology section of the Union of European Medical Specialists and the European Board of Gastroenterology is to be enacted in the near future. ${ }^{4}$

Audit - this is a very important area regarding, for example, cost effectiveness of clinical practice, the judicious use of endoscopy, gastrointestinal diagnostic procedures, reimbursement practices, and issues of manpower. It is important to codify the existing practices in each European country and analyse the data to determine optimal future strategies.

Ethics - with the rising complexity of medical practice, expensive technology, and economic constraints, issues of ethics are brought into focus. Seminars and symposiums on ethics have been presented sporadically at major gastrointestinal meetings. Similarly the contribution of the ethics committee of OMGE is commendable, but as ethical matters arise, further work is required.

To pursue and consolidate these activities in Europe, the initiative should originate primarily from associations with national representation, to set up working groups with experts nominated by their national society of gastroenterology. It is obvious that this ambitious endeavour will require a central organisation and national representation, funds, expertise, and more than anything else time and dedication. ASNEMGE is already moving in this direction.

The current scene and the forces that operate in European gastroenterology are mature and conducive for such undertakings. Bridges of scientific communication have been built and the European Union is a reality in our lives. Seize the opportunity to open new avenues of European cooperation in gastroenterology.

CONSTANTINE ARVANITAKIS

First Department of Medicine,

University of Thessaloniki School of Medicine,

Thessaloniki 54006, Greece

1 Standaert LO. History of ASNEMGE. Gastroenterology International 1993; 6: 180-6.

2 Arvanitakis C. Opening Address, First United European Gastroenterology Week - Athens 92. Gastroenterology International 1993; 6: 61-2.

3 Torsoli A, Fais S, Ulissi A, Sebastiani R, Dowling RH. The export of European Gastrointestinal science - The case for export of European Gastrointestinal science - The case for In annual scientific meeting

4 Mallinson CN. Specialist training in gastroenterology in the European Community - the case for European Boards. Gut 1994; 35: 135-8. 